\title{
Konflikt i zmiana pokoleniowa w rosyjskim polu literackim po 2000 roku. Przypadek nowego realizmu
}

\author{
Abstract \\ Generational Conflict and Change in the Russian Literary Field after 2000. A Case of the New \\ Realism
}

This article aims to present the key post-Soviet generational conflict in the Russian literary field, which has significantly influenced the present shape of the field. The most important mechanisms and stages of the discussed generational change, its institutional background and the most important actors of these processes will be highlighted. For the purpose of the text, manifestos, critical essays, interviews, polemics and other forms of expression on (around) literary issues published in literary magazines such as "Novy mir", "Kontinent", "Oktyabr", "Znamya", "Voprosy literatury", "Ural”, "Literaturnaya gazeta", "Literaturnaya Rossiya", "NG Ex Libris" and the daily press, which is not profiled in literary terms. The basis of the research is the perspective of the social history of literature, based on two important theoretical approaches to the relationship between literature and social reality: the concept of the sociology of the literary field by Pierre Bourdieu and the concept of aesthetics as politics by Jacques Rancière.

Keywords: the new realism, generational conflict, Russian literary field, Russian literature after 2000

Słowa kluczowe: nowy realizm, konflikt pokoleniowy, rosyjskie pole literackie, literatura rosyjska po 2000 roku

Lata dziewięćdziesiąte XX wieku w rosyjskim polu literackim dały przestrzeń na realizację kolejnej odsłony sporu między frakcjami pola o poglądach liberalno-demokratycznych i konserwatywno-nacjonalistycznych. Na gruncie literackich konwencji i kierunków konkurowały ze sobą przede wszystkim postmodernizm, krzewiony i popularyzowany przez liberałów jako nurt pełnej wolności estetycznej, oraz realizm, zdyskredytowany po rozpadzie ZSRR i broniony na wszelkie sposoby przez konserwatystów, którzy podejmowali próby odbudowy jego zna- 
czenia. Rok 2000 został zgodnie uznany przez obie strony sporu za moment kluczowy w rozwoju rosyjskiego pola literackiego po rozpadzie ZSRR - dla strony konserwatywnej stał się on symbolicznym początkiem odnowy, zaś dla liberałów początkiem upadku rosyjskiej literatury. Zmiany w polu literackim sprzęgnięte były z przełomem społeczno-politycznym w Rosji, związanym ze słabnącą pozycją prezydenta Borysa Jelcyna, a zwieńczonym przejęciem władzy przez Władimira Putina. O ile w sporze z lat dziewięćdziesiątych brali udział przede wszystkim przedstawiciele pokolenia lat pięćdziesiątych i sześćdziesiątych XX wieku, a więc ci pisarze, krytycy oraz inni przedstawiciele pola, którzy rozpoczynali swoje literackie kariery jeszcze w Związku Radzieckim, o tyle wspomniany rok 2000 stał się czasem debiutu dla pisarzy młodego pokolenia, urodzonych w większości w latach siedemdziesiątych i osiemdziesiątych, którzy zgrupowali się pod szyldem nowego realizmu i definitywnie odcięli się od obu stron starego konserwatywno-liberalnego sporu.

\section{Negacja żałoby}

O ile podejmowane wcześniej próby zrehabilitowania realizmu (także pod szyldami neo- lub postrealizmu) wychodziły od środowisk, które albo utraciły dominację lub wysoką pozycję w polu wraz z upadkiem ZSRR, albo nie zdążyły ich w pełni zyskać, o tyle w roku 2000 głos zaczynają zabierać niezależni i nieznani przedstawiciele młodego pokolenia. Stali się oni trudniejszymi niż „starzy” konserwatyści przeciwnikami dominującej ówcześnie strony liberalnej między innymi dlatego, że nie można było ich nazwać nostalgikami po dawnym porządku - co było istotnym argumentem wymierzonym przeciwko stronie konserwatywnej.

W związku ze ,zmianą warty” dyskusja wewnątrz pola nabierała coraz większej dynamiki. Jak się wydaje, zwiększenie aktywności polemicznej po stronie liberalnej mogło być związane z poczuciem końca dominacji - o ile jeszcze w latach dziewięćdziesiątych XX wieku liberałowie byli w stanie swobodnie wyznaczać reguły gry w polu, o tyle w młodym pokoleniu nowych realistów dostrzegli istotne zagrożenie. Symbolicznym początkiem tej zmiany był manifest literacki Siergieja Szargunowa (ur. 1980) z 2001 roku zatytułowany Negacja żałoby ${ }^{1}$, którego tytuł jest bezpośrednim i polemicznym odniesieniem do manifestu Wiktora

\footnotetext{
1 S. Szargunow, Otricanije traura, „Nowyj Mir” 2001, nr 12, http://magazines.russ.ru/novyi_ mi/2001/12/shargunov.html (dostęp: 1.07.2019). Co istotne, Szargunow nie był jedynym pisarzem, który przypisywał sobie autorstwo pierwszego manifestu nowego realizmu. Dmitrij Cziornyj (ur. 1975) twierdził, że pierwszym manifestem był jego tekst zatytułowany Manifest radikalnogo realizma, napisany już w marcu 2000 roku, a więc przynajmniej kilka miesięcy przed Negacją żałoby (zob. D. Cziornyj, Manifiest radikalnogo riealizma, ,Stihi.ru”, 30.03.2000, http://stihi.ru/2011/04/05/4307 (dostęp: 1.07.2019). W 2001 roku Cziornyj wydał nawet książkę Manifest i mietody radikalnogo riealizma (Moskwa 2001), w której rozszerzał swój manifest i wskazywał pożądane drogi rozwoju nowego nurtu. Mimo tych wysiłków Cziornemu nie udało się uprawomocnić swojej pozycji w polu, a rosyjska krytyka literacka konsekrowała Siergieja Szargunowa jako oficjalnego autora pierwszego manifestu nowego realizmu. Oficjalna strona Cziornego (http://radreal.su) stanowi - poboczną względem głównego nurtu nowego realizmu - próbę kontynuowania projektu radykalnego realizmu.
} 
Jerofiejewa pod tytułem Stypa po literaturze sowieckiej², uznanego za proklamację postmodernizmu w Rosji. Recepcja manifestu nie była jednoznaczna. Andriej Niemzier, jeden z najbardziej wpływowych liberalnych krytyków literackich, nazwał go „bezczelnym, niekulturalnym artykułem”3, natomiast Siergiej Bielakow, przedstawiciel młodszego pokolenia liberalnych krytyków, zauważył, że był on „początkiem mitu”, który dał impuls do jednoczenia się debiutujących krytyków i pisarzy pod wspólnym szyldem nowego realizmu.

Manifest Szargunowa spełnia podstawowe cele odezwy literackiej nastawionej na wprowadzenie w obieg środowiskowy nowego zjawiska. Zapowiada on nadejście nowej grupy, dla której najważniejszym zadaniem miałoby być doprowadzenie do odrodzenia, nie tylko w obszarze rosyjskiej literatury, ale także szerzej, w życiu społecznym. Istotnym czynnikiem zapowiadanej odnowy był właśnie aspekt pokoleniowy. Szargunow buduje analogię między własną generacją a okresem srebrnego wieku, który zresztą uznaje za wzorzec: „Jak wiadomo, kwiatem «rosyjskiego renesansu» było pokolenie urodzone w latach osiemdziesiątych i dziewięćdziesiątych XIX wieku. I oto mamy też takie pokolenie sto lat później, które kształtowało się przeddzień i dzień po pieriestrojce"s. W ramach tej analogii Szargunow najchętniej porównywał nowy realizm z ówczesnym akmeizmem - nurtem literackim programowo odżegnującym się od niejednoznaczności w poezji oraz skupiającym się na konkretnych aspektach rzeczywistości. Tak jak akmeizm był prądem rewizjonistycznym wobec niektórych tendencji modernistycznych - na przykład występował przeciwko symbolizmowi (z jego wieloznacznością) oraz futuryzmowi (z jego oderwaniem od rzeczywistości) tak samo proklamowany przez Szargunowa nowy realizm miał przeciwstawiać się postmodernistycznej niejednoznaczności, nieklarowności oraz oderwaniu od rzeczywistości. Odrodzenie literatury powinno, zdaniem pisarza, nastąpić w jej klasycznym, realistycznym kształcie.

Deklaracja ideowa nowego pokolenia wskazuje jasno oponentów, przeciwko którym występują. Z jednej strony są to postmoderniści, z drugiej natomiast stare elity, które swoją bezradnością doprowadzić miały do katastrofalnego stanu rosyjskiej literatury, związanego z jej postępującym urynkowieniem, utowarowieniem oraz komercjalizacją - a więc zasadniczo z efektami wycofania się państwa $\mathrm{z}$ obszaru kultury oraz oddania tejże pod władanie wolnego rynku. Ta diagnoza, antykapitalistyczna w swej wymowie, implikuje między innymi postulat mówiący o konieczności przywrócenia literaturze jej społecznego charakteru.

Według manifestu społeczną misją literatury miałoby być docieranie do mas, ale - co istotne - w formie literatury „poważnej”, nie zaś „,popularnej”. Wprowadzone przez Szargunowa rozróżnienie trzech typów literatury: elitarnej, masowej poważnej i masowej popularnej, będzie zresztą regularnie powracać w toczącym

2 W. Jerofiejew, Stypa po literaturze sowieckiej, przeł. A. Pomorski, „Res Publica” 1991, nr 6, s. $36-41$.

3 S. Biełakow, Nowyje bielinskije i gogoli na czas, „Woprosy litieratury” 2007, nr 4, http://voplit. ru/eText/2007/2007-4/2007-4/2007-4.html\#79 (dostęp: 1.07.2019).

4 Ibid.

5 S. Szargunow, Otricanije traura, op. cit. Tu i dalej - tłumaczenie własne. 
się sporze o nowy realizm. Za wzór literatury masowej poważnej, będącej literackim ideałem i domniemanym owocem całej tradycji kultury rosyjskiej, Szargunow stawia między innymi twórczość klasycznych realistów dziewiętnastowiecznych - przede wszystkim Maksyma Gorkiego (jako symbolu realizmu ideowego) oraz radzieckich pisarzy realistów. Kategoria literatury masowej poważnej mieści w sobie oczekiwanie pisarstwa egalitarnego skierowanego do różnych klas społecznych - również, a może przede wszystkim, do tych, które nie posiadają wysokiego kapitału kulturowego. Z kolei oczekiwanie, aby literatura nowego pokolenia była poważna, to przede wszystkim przeciwstawienie się dominacji postmodernizmu, który chętnie operował ironią i pewną ,grą" literacką.

W tym kontekście Negacja żałoby to obietnica zwrócenia się ku „prawdzie rzeczywistości”, która była odpowiedzią na postmodernistyczną ucieczkę w świat symulakrów. Zdaniem Szargunowa młode pokolenie powinno raczej konfrontować się z zastaną rzeczywistością. Jak twierdzi:

Człowiekowi z nowego rosyjskiego pokolenia nie przyjdzie do głowy parodiowanie otaczającej go rodzimej rzeczywistości, tym bardziej nie będzie on sięgał po grymasy nieznanego mu radzieckiego okresu. W tym zawiera się jedyna prerogatywa postmodernistów. Prawidłowość ich istnienia, ich rola to „zakrakać” nowy czas historyczny. Postmodernizm to zegar śmiechu. Śmiejąc się, rozstają się z przeszłością. Śmiejąc się, izolują się od nowo narodzonej teraźniejszości. Młody człowiek jest wpisany w swoje środowisko i swoją epokę, świeżo patrzy na świat, cokolwiek by się w tym świecie dotychczas działo... Dwaj starsi bracia (Wiktor Pielewin i Władimir Sorokin) z rozmachem chichoczą nad bezradnym ojcem Noem (tradycyjną literaturą), ale młodszy brat nie chce się śmiać. Nadchodzi zamiana śmiechu. Nadchodzi nowy realizm ${ }^{6}$.

Szargunow przedstawia młode pokolenie nowych realistów jako awangardę zmiany społecznej działającą w poprzek utartych podziałów. Neguje podział na konserwatyzm i liberalizm (dokonując tym samym aktu symbolicznego unieważnienia sporu $\mathrm{z}$ lat dziewięćdziesiątych) i proponuje zupełnie nowy podział. Na jego jednym biegunie leżałyby poprawność polityczna, oportunizm i chęć dopasowania do warunków narzucanych polu literackiemu przez inne pola, na drugim zaś - bunt, protest, opozycyjność i marginalność. Pojawienie się młodego pokolenia nowych realistów na tym drugim biegunie ma być, zdaniem Szargunowa, sprzęgnięte z procesami zmiany społecznej zachodzącymi na całym świecie:

Pojawił się nowy kontekst, w którym pisarz daleki jest od uprzedzeń i ideowego pancerza. Samo geopolityczne przeciwstawienie ustąpiło innym wariantom. I nie jest to monopolarność. „Triumf USA” jest zwycięstwem pyrrusowym. Oberwano róg radziecki, na którym opierał się róg amerykański, naruszono równowagę, przez co świat staje się niezdyscyplinowany i niepoprawny politycznie oraz barwny. Rosyjska literatura w efekcie niepojętych trajektorii chce zaryzykować i znaleźć się w awangardzie nowego procesu. Dla literatury jest to możliwość bycia wolną?

Ambicje młodego pokolenia wydają się więc wyjątkowo duże i nie ograniczają się wyłącznie do kontekstu narodowego. Wyraźne - mimo że niewypowiadane

6 Ibid.

7 Ibid. 
wprost - jest tutaj także oczekiwanie na zmianę gwałtowną, rewolucyjną, rozumianą jako batalia o lepszą literaturę i rzeczywistość.

Awangarda literacka jest dla Szargunowa także awangardą zmiany społecznej, a jej główne zadanie to uporządkowanie „ogrodu sztuki, w którym zawsze glebą jest realność, a korzeniami - ludzie"8. W Szargunowowskiej wizji ogrodu sztuki, bogatego w różnorodną roślinność, nowy realizm przyrównany jest do róży. Róża ta stanowi zwiastun pojawienia się ,,[... rytmiczności, jasności oraz lakoniczności. To alternatywa dla postmodernizmu, w której jawa nie będzie już mętna, szarańcza zginie, a duch dawnej tradycyjnej literatury na nowo zacznie oddychać"9.

\section{Debata, czyli zagrożeni liberałowie}

Stawiane przez Szargunowa pytanie o stosunek literatury do rzeczywistości stało się kluczowym aspektem burzliwej debaty w kolejnych latach. Podstawowym wymiarem debaty stał się sam konflikt, a jej wyraźnym celem - udział w walce o dominację w polu. Najistotniejszymi przykładami wydają się tutaj: seria polemik na temat nowego realizmu publikowanych na łamach czasopisma „Woprosy litieratury" w 2007 roku ${ }^{10}$, polemika wokół artykułu Olgi Martynowej Pozagrobowe zwycięstwo socrealizmu ${ }^{11}$ z 2009 roku oraz dyskusja na łamach ,Litieraturnoj gaziety" w 2010 roku $^{12}$.

O konfliktowym nade wszystko wymiarze debaty i radykalizacji stosunków w polu literackim świadczą tytuły tychże polemik (często militarne w duchu, takie jak Nie jesteśmy kastratami, jesteśmy - żotnierzami, Strategicznie wygraliśmy ${ }^{13}$ ), sposoby określania przeciwników sporu (np. specnazowcy ducha ${ }^{14}$ ) oraz tytuły utworów literackich nowego realizmu (jak np. Hura! czy Alonka partyzantka ${ }^{15}$ ). To konfliktowe, retorycznie agresywne podejście młodego pokolenia nowych realistów uruchomiło po stronie liberalnej mechanizm negacji, który polegał głównie na próbach stygmatyzowania, bagatelizowania lub ośmieszania przeciwnika. Tutaj warto przytoczyć takie tytuły polemik, jak: Potwór o stu paszczach i bez języka, Uwolnieni radykałowie, Smok w labiryncie: ślepy zaułek nowego realizmu, Bielińscy $i$ Gogole na godziny, Nowyprzenowy realizm, albo znów dwadzieścia

8 Ibid.

9 Ibid.

10 Zob. „Woprosy Litieratury” 2007, nr 3-5, szczególnie teksty S. Biełakowa, A. Rudalowa, N. Iwanowej i Ż. Golienko.

11 O. Martynowa, Zagrobnaja pobieda socriealizma, „OpenSpace.ru”, http://os.colta.ru/literature/ events/details/12295/ (dostęp: 1.07.2019).

12 Zob. „Litieraturnaja gazieta” 2010, nr 9 (6264) - 13 (6268) i 16-17 (6272).

13 I. Aksienow, My nie kastraty, my - sołdaty, „NG-Exlibris”, 18.11.2004, http://www.ng.ru/ ng_exlibris/2004-11-18/6_soldiers.html (dostęp: 1.07.2019); S. Szargunow, Stratiegiczieski my pobiedili, ,Kontinient” 2005, nr 125, http://magazines.russ.ru/continent/2005/125/sh26-pr.html (dostęp: 1.07.2019).

14 W. Orłowa, Diebiut wieczien, „NG-Exlibris”, 18.11.2004, http://www.ng.ru/ng_exlibris/2004-11-18/6_debut.html (dostęp: 1.07.2019).

15 S. Szargunow S., Ura!, Moskwa 2003; K. Buksza, Alonka-partizanka, Sankt Petersburg 2002. 
pięć czy wspominane już Pozagrobowe zwycięstwo socrealizmu ${ }^{16}$. Wśród najciekawszych określeń, których zadaniem było ośmieszenie lub wyraźne zlekceważenie twórców i twórczości nowego realizmu, znalazły się takie, jak: szarańcza, barbarzyńcy literatury czy piranie ${ }^{17}$. Sam nowy realizm bywał nazywany ,syndromem przewlekłej choroby", negatywnie ocenieni zostali także odbiorcy i entuzjaści nowej literatury - ich gust miał być wyrazem ,,zaostrzenia apetytu na kartofle ze skwarkami"18. Zdaniem Ilji Kukulina - krytyka i literaturoznawcy, który w całym sporze starał się zajmować wyważoną pozycję bezstronnego eksperta to nieustępliwe kontestowanie nowego realizmu i kwestionowanie jego istnienia przez stronę liberalną jedynie potwierdzało jego istotę ${ }^{19}$. Poza nieudanymi próbami deprecjacji i zanegowania istnienia nowych tendencji literackich w polu strona liberalna przyjęła także strategię dowartościowania konsensusu jako właściwego sposobu prowadzenia debaty - jej przedstawiciele wychodzili z propozycjami pogodzenia założeń konkurujących nurtów i środowisk ${ }^{20}$. W związku z brakiem zainteresowania po drugiej stronie próby wznowienia konsensualnego porządku pola okazały się jednak tylko krótkotrwałym epizodem.

Po tym jak strategie ignorowania, dewaluacji i stygmatyzacji oraz poszukiwania konsensusu okazały się zawodne, znajdująca się w coraz głębszej defensywie strona liberalna podjęła próbę obrony swojego ostatniego bastionu, czyli koncepcji ,sztuki dla sztuki”, mającej się realizować w literaturze czystej, autonomicznej i skupionej na samej sobie, na własnym języku. Argumenty na rzecz tego apolitycznego podejścia mówiły, z jednej strony, o potrzebie pluralizmu ${ }^{21}$ zarówno w obszarze tematów literackich, jak i postaw samych pisarzy, z drugiej jednak uparcie odmawiały młodemu pokoleniu nowych realistów prawa do stanowienia jednego z równoprawnych biegunów takiego pluralistycznego pola, zarzucając

16 I. Frołow, Czudiszcze stoziewno i biezjazyko, „Litieraturnaja gazieta” 2010, nr 11 (6266), http://www.lgz.ru/article/N11--6266---2010-03-24-/Chudisht\%D0\%B5-stoz\%D0\%B5vno-i-b\%D0\%B5zayaz\%D1\%8Bko12025/ (dostęp: 1.07.2019); M. Bojko, Swobodnyje radikaty-2. Manifiest proigrawszej storony, ,NG-Exlibris”, 25.02.2010, http:/www.ng.ru/ng_exlibris/2010-02-25/5_radikaly2.html (dostęp: 1.07.2019); S. Biełakow, Drakon w tabirintie: k tupiku nowogo riealizma, „Urał” 2003, nr 10, http://magazines.russ.ru/ural/2003/10/bel.html (dostęp: 1.07.2019); S. Biełakow, Nowyje bielinskije..., op. cit.; D. Markowa, Nowyj-prienowyj riealizm, ili opiat'dwadcat'piat', ,Znamia” 2006, nr 6, http://magazines.russ.ru/znamia/2006/6/ma12.html (dostęp: 1.07.2019); O. Martynowa, op. cit.

17 I. Frołow, op. cit.

18 M. Lipowieckij, Nowyj riealizm - eto rannij simptom zatjażnoj boliezni, „Colta.ru”, 23.04.2014, http:/www.colta.ru/articles/literature/3003 (dostęp: 1.07.2019); S. Biełakow, Drakon w łabirintie..., op. cit.

19 I. Kukulin, „Kakoj szcziot?” Kak gławnyj wopros russkoj litieratury, „Znamia” 2010, nr 4, http://magazines.russ.ru/znamia/2010/4/ku19.html (dostęp: 1.07.2019).

20 W. Szubinskij, Szto i pocziemu, „Oktiabr”, 2010, nr 2, http://magazines.russ.ru/october/2010/2/s15.html (dostęp: 1.07.2019); S. Biełakow, Zabłudiwszijsja drakon, „Czastnyj korriespondient", 17.03.2010, http://www.chaskor.ru/article/zabludivshijsya_drakon_15990 (dostęp: 1.07.2019); Ż. Golenko, Czitat' modno!, „Woprosy litieratury” 2004, nr 5, http://voplit.ru/ eText/2004/2004-5/2004-5/2004-5.html\#6 (dostęp: 1.07.2019).

21 N. Rubanowa, Kiłogrammy bukw w razwies $i$ w rozliw, ,Znamia” 2006, nr 5, http://magazines. russ.ru/znamia/2006/5/ru15.html (dostęp: 1.07.2019); W. Szubinskij, op. cit. 
im, między innymi, dyktaturę chamstwa, populizm literacki, rehabilitację sowieckiego smaku, czy ubóstwo, marudność i mrocznośćc2.

O tym, że nowy realizm nie istnieje, przekonywano na różne sposoby. Przejawiało się to chociażby w długo toczącej się debacie na temat nazwy. Pierwszym zarzutem była wtórność terminu. Z jednej strony, jak dowodzili liberałowie, nowy realizm przywodził na myśl skojarzenie z neorealizmem włoskim lat czterdziestych i pięćdziesiątych XX wieku oraz francuskim nowym realizmem - ruchem artystycznym z lat sześćdziesiątych XX wieku. Z drugiej strony, nowy realizm niejednokrotnie pojawiał się również na kartach rosyjskiej historii literatury w latach dwudziestych i trzydziestych XX wieku mianem tym krytycy określali prozę modernistyczną, zwracając przede wszystkim uwagę na twórczość Andrieja Biełego, Jewgienija Zamiatina, czy Fiodora Sołoguba ${ }^{23}$. Siergiej Biełakow, jeden z głównych oponentów nowego realizmu, już w 2003 roku przekonywał nawet, że „nowy realizm jest tylko reinkarnacją pojawiającego się periodycznie radykalnego realizmu"24, którego cel to tylko lustrzane odbijanie rzeczywistości. Poza wtórnością nowy realizm miał być określeniem pozbawionym mocy, a to ze względu na akcentowanie już w swojej nazwie aspektu chronologicznego. Przeciwnicy zjawiska pytali przy tej okazji o to, jaki miałby być następny punkt tego kontinuum: ,nowy, nowszy, najnowszy, nowy-nowy?”25.

Nie tylko przeciwnicy nowego realizmu występowali z postulatami innej nazwy. Przychylny młodemu pokoleniu konserwatywny Władimir Bondarienko proponował akcentowanie raczej orientacji politycznej ruchu, sugerując terminy nowi lewicowi radykałowie, nowa lewica, nowa socjalna literatura lub literatura protestu ${ }^{26}$, upatrując $\mathrm{w}$ tym, być może, międzygeneracyjnego sojuszu literatów. Jewgienij Jermolin z kolei proponował trans-awangardę, przy czym prefiks „trans-” miałby sugerować możliwość eksportu tej literatury za granicęę. Nawet Walerija Pustowaja, pierwsza ideolożka nowego realizmu, poszukiwała

22 I. Frołow, op. cit.; N. Rubanowa, op. cit.; O. Martynowa, op. cit.; M. Bojko, Swobodnyje radikaty-2...

23 M. Bojko, O diwnyj nowyj riealizm, „Litieraturnaja gazieta” 2010, nr 12 (6267), http://www. lgz.ru/article/N12--6267---2010-03-31-/O-divn\%D1\%8By-nov\%D1\%8By-r\%D0\%B5alizm12106/ (dostęp: 1.07.2019). Autor cytuje fragment krytycznoliterackiej twórczości Aleksandra Woronskiego Iskusstwo widiet' mir (1929), w którym krytyk nazywa nowym realizmem właśnie prozę Andrieja Biełego. Ponadto problematyka modernistycznego neorealizmu lub nowego realizmu ma swoje szczegółowe opracowania w literaturze podmiotu. Zob. T. Dawydowa, Russkij nieoriealizm: idieołogija, poetika, tworczieskaja ewolucija (E. Zamiatin, I. Szmielew, M. Prisziwin, A. Płatonow, M. Bułgakow $i d r$.): Ucziebnoje posobije, Moskwa 2006; S. Tuzkow, I. Tuzkowa, Nieoriealizm: żanrowo-stilewyje poiski w russkoj litieraturie końca XIX - naczała XX wieka: Ucziebnoje posobije, Moskwa 2009.

24 S. Biełakow, Drakon w tabirintie...

25 M. Bojko, Wzlot i padienije N-riealizma, Materiały Konferencji Związku Pisarzy Rosji Itogi litieraturnogo goda-itogi diesiatiletija: jazyk-litieratura-obszczestwo, Moskwa 2010, http://www. rospisatel.ru/konferenzija/boiko.htm (dostęp: 1.07.2019).

26 W. Bondarienko, Nuliewyje, Materiały Konferencji Związku Pisarzy Rosji Itogi ...; W. Bondarienko, Popytka prorywa, „Litieraturnaja Gazieta” 2010, nr 13 (6268), http://www.lgz.ru/article/ N13--6268---2010-04-07-/Pop\%D1\%8Btka-pror\%D1\%8Bva12210/ (dostęp: 1.07.2019).

27 J. Jermolin, Molodoj Kontinient, „Kontinient” 2005, nr 125, http://magazines.russ.ru/continent/2005/125/ee1.html (dostęp: 1.07.2019). 
nazwy, która rezygnowałaby z przymiotnika nowy. Proponowała realizm metafizyczny lub symboliczny ${ }^{28}$, co zostało szybko skrytykowane przez oponentów jako sprzeczność między proponowanym przez młodych pisarzy skupieniu na konkretnych, materialnych aspektach rzeczywistości a transcendencją, metaforą, symbolami i poszukiwaniami wiecznych, uniwersalnych wartości w twórczości meta-realistów ${ }^{29}$.

Wreszcie, na kanwie przemian wewnątrz pola, pojawiły się postulaty zakorzenienia nowego realizmu w nieco już zapomnianym realizmie krytycznym. Ta kategoria literaturoznawstwa marksistowskiego stosowana była do charakterystyki realizmu o charakterze demaskatorskim wobec przemian społecznych sprzed socrealizmu. Tutaj szczególnie interesujący wydaje się Manifest nowego rosyjskiego krytycznego realizmu ${ }^{30}$ Aleksieja Jaszina, w którym autor przedstawia 22 tezy na temat rekomendowanych dróg rozwoju literatury rosyjskiej. Jaszin próbuje ostatecznie zinstytucjonalizować nowy realizm jako prawowitego dziedzica realizmu krytycznego. Jednym z ciekawszych aspektów manifestu Jaszina jest wypowiadane tam przekonanie o tym, że literatura realistyczna jest narzędziem zmiany społecznej oraz wyrazem procesu formowania idealnego społeczeństwa, zaś pisarz, niezależnie od tego, czy ma poglądy lewicowe, czy prawicowe, zawsze powinien stać w opozycji wobec dominującej formacji władzy. Jaszin przekonuje także, że nowy rosyjski realizm, choć ma swoje cechy wyjątkowe, jest tylko częścią globalnej zmiany społecznej.

Ponadto, jak słusznie i dość zgodnie zauważają zarówno niektórzy krytycy ${ }^{31}$, jak i zwolennicy nowego realizmu ${ }^{32}$, forsowanie przymiotnika nowy jest próbą odnalezienia swojego miejsca w polu, wyróżnienia się na tle innych, dobrze zakorzenionych tam zjawisk. Taka próba autolegitymizacji poprzez symboliczne wtargnięcie w zamknięte, jasno zdefiniowane w drugiej połowie lat dziewięćdziesiątych granice pola literackiego, z efektem awangardowej świeżości, projektem zmiany reguł gry i nowym dyskursem, jest stałym elementem podtrzymującym życie pola.

O tym, że nowy realizm był przede wszystkim mitem założycielskim i kartą przetargową nowego literackiego pokolenia w Rosji, nie zaś spójnym nurtem literackim, mówiło się w tej debacie wprost:

Pisarze, których uznaje się za „nowych realistów”, są słabo ze sobą związani. Między sentymentalną prozą Zachara Prilepina, krytycznym realizmem Romana Sienczina, neoawangardą Siergieja Szargunowa i ,prawdą okopów” Arkadija Babczenko jest niewiele

28 W. Pustowaja, Porażiency i prieobrażiency (o dwuch aktualnych wzgladach na riealizm), „Oktiabr”" 2005, nr 5, http://magazines.russ.ru/october/2005/5/pust18.html (dostęp: 1.07.2019).

29 M. Bojko, Wzlot i padienije ..., op. cit.; Bojko przypomina także, że termin metafizyczny realizm lub metarealizm, kojarzony z nazwiskami Jurija Mamlejewa oraz Michaiła Epsztejna, był używany w rosyjskim polu literackim od lat 70. XX wieku, natomiast realizm symboliczny to kolejne określenie na prozę modernistyczną z początku XX wieku.

30 A. Jaszin, Manifiest nowogo russkogo kriticzieskogo riealizma, „Priokskije Zori” 2011, nr 1, http://www.rospisatel.ru/manifest-nkr.htm (dostęp: 1.07.2019).

31 S. Biełakow, Nowyje bielinskije..., op. cit.; D. Markowa, op. cit.

32 A. Bołszakowa, Sowriemiennyj litieraturnyj proces: tiendencii i pierspiektiwy, Materiały Konferencji Związku Pisarzy Rosji Itogi... 
wspólnego. Nie przypadkiem ci, których nie tak dawno postrzegano jako liderów nowego realizmu - Aleksandra Karasiewa, Dmitrija Nowikowa, Denisa Gucko - publicznie się od niego odcięli. Natomiast Roman Sienczin, który teraz jest „głównym nowym realistą”, na początku nie był przez nich przyjęty ${ }^{33}$.

Krytycy przychylni młodym traktują zresztą tę niespójność i eklektyzm jako atut i pożądany przejaw naturalnych przemian, jakie zaszły w łonie samego klasycznego realizmu po modernizmie i postmodernizmie - ich zdaniem nowy realizm ma być oczekiwanym rozpoczęciem debaty na temat poszerzania granic samego realizmu ${ }^{34}$. Pomysłów na rozszyfrowanie nowego realizmu jako nurtu literackiego i prób zebrania wszystkich jego literackich korzeni, wpływów, kluczowych szkół i temu podobnych zjawisk było zresztą wiele. Alisa Ganijewa (ur. 1985), jedna z pisarek i krytyczek włączanych w poczet nowego realizmu, wylicza następujące elementy konwersji literackich stylów w ramach nowego realizmu:

[...] modernistyczna obcość i sprzeczność, postmodernistyczne zmęczenie, eschatologia, ciałocentryczność, barokowy kontrast i transformacje, naturalistyczna fizjologiczność i dokumentalizm, neobarokowy nadmiar, fragmentaryczność, [...] romantyczny protest, antagonizm i pociąg do poszukiwań, co może się realizować w pełni realistycznym smutku i zwykłych okolicznościach (jak w kronice codzienności u Sienczina). Są tu i cechy neoromantyzmu (rewolucyjny indywidualizm, mistyczne poszukiwania) i wyraźna cecha tradycjonalizmu, które w młodej prozie wyrażają się poprzez reakcyjne idee wymierzone przeciwko współczesnej kondycji społeczeństwa $[\ldots]^{35}$.

Sami nowi realiści ani ich promotorzy nie próbowali zresztą nigdy negować pojemności pojęcia nowy realizm, ani też faktu, iż nie był on nigdy spójnym nurtem estetycznym. Spoiwem nowego realizmu od samego niemal początku było kryterium polityczne ${ }^{36}$.

\section{Konsekracja i zdobywanie dominacji w polu}

Nowy realizm miał być zatem znakiem rozpoznawczym, dystynkcją młodego literackiego pokolenia. Strona liberalna eksponowała ten aspekt generacyjny, by udowodnić, że nowy realizm został sztucznie stworzony i wypromowany przez starszą generację konserwatystów, a więc że istnieje on wyłącznie jako rynkowy produkt środowiskowej inżynierii społecznej. Zabieg ten interpretowano jako podjętą przez ,starych” konserwatystów próbę osiągnięcia dominacji w polu przy użyciu pojęcia młodej literatury - ale bez faktycznego otwarcia przestrzeni dla młodych, niezależnych autorów. Niektórzy krytycy liberalni wieszczyli nowym

33 S. Biełakow, Istoki $i$ smyst nowogo riealizma: $k$ litieraturnoj situacii nulewych, Materiały Konferencji Związku Pisarzy Rosji Itogi...

34 A. Bołszakowa, op. cit.

35 A. Ganijewa, Wozrożdienije koncepta ,,Mołodyje pisatieli” w nuliewyje gody, Materiały Konferencji Związku Pisarzy Rosji Itogi...

36 Ograniczenia formalne oraz koncepcja niniejszego artykułu nie pozostawiają zbyt wiele miejsca na rozwinięcie tej tezy. Zagadnieniu poświęcona została rozprawa doktorska autorki, która w niedługim czasie ukaże się w druku. 
realistom rychły koniec, dowodząc kruchości samego pojęcia młodej literatury i zwracając uwagę na czysto środowiskowy wymiar tego projektu. Taką tezę stawiała na przykład Daria Markowa:

[...] na tego perspektywicznego czarnego konia, stawiają niektórzy starsi pisarze i krytycy. W rezultacie ta napędzana nagrodami i projektami część młodego pokolenia nie tylko żyje i pisze, ale przede wszystkim manifestuje, odczuwa swoją wyjątkową misję odrodzenia literatury, w związku czym ich utwory często ciekawiej się analizuje, niż czyta ${ }^{37}$.

Nieprawdziwość i ulotność zjawiska stwierdzał też Siergiej Biełakow, który odnotował istnienie nowego realizmu tylko w treści manifestów i polemik, zaznaczając, że jest to przede wszystkim główny mit - a nie główny nurt - pierwszej dekady XX wieku:

Mimo wszystko nowy realizm, w tym sensie, w jakim rozumieli go Siergiej Szargunow, Walerija Pustowaja i Andriej Rudalow, istniał tylko w manifestach. Oni po prostu oszukiwali samych siebie, starając się wyjść ze ślepego zaułka, w którym utknęła nasza ,poważna" proza w latach dziewięćdziesiątych. To była tylko nadzieja przywrócenia literaturze społecznego znaczenia i miłości czytelnika, wlania w nią soków życia ${ }^{38}$.

Wśród rzekomych „inżynierów nowego realizmu”, często też nazywanych „lobbystami”, wspominani są prominentni krytycy starszego pokolenia, między innymi Paweł Basinski, Oleg Pawłow, Irina Rodnianska czy Olga Sławnikowa. Ta ostatnia nazwała zresztą nowych realistów pokoleniem next ${ }^{39}$. Chociaż z jednej strony Sławnikowa ocenia sucho ich twórczość - występując z pozycji autorytetu i osoby dobrze osadzonej w polu literackim, zwraca uwagę na ich naiwność i ignorancję - to z drugiej strony cechy takie jak pewność siebie i swoisty genialny egocentryzm młodego pokolenia rzeczywiście zdają się fascynować Sławnikową do tego stopnia, że jej esej staje się peanem wyznaczającym dyskurs na temat młodych pisarzy na wiele lat naprzód. Jej fascynacja opiera się na czysto psychologicznych obserwacjach, z których wynika, że młodzi nowi realiści są przede wszystkim gniewni, zuchwali i intrygujący.

Warto w tym miejscu zauważyć, że Sławnikowa, namaszczając nowych realistów na czołowych młodych buntowników literackich, nie wychodzi poza klasyczny schemat procesu konsekracji, w którym uznany uczestnik pola (pisarz czy krytyk literacki) zmuszony jest uznać siłę grupy nowych graczy w polu (dotychczasowej bohemy) i symbolicznie zalegitymizować ich istnienie, zapewniając samemu sobie pozycję ich odkrywcy, krzewiciela, a przez to sojusznika danego zjawiska. Jednocześnie Sławnikowa wyraźnie wątpi w trwałość nowego reali$z m u$ - przewiduje, że to zjawisko zostanie wchłonięte przez stabilną część pola, która ma swoje wyraźne, ustalone reguły. Tym samym występuje ona jako obrończyni ortodoksji, która wprawdzie otwiera nowym realistom furtkę do uporządkowanego rosyjskiego pola literackiego, ale nie dopuszcza możliwości zmiany wewnętrznych reguł gry w polu.

37 D. Markowa, op. cit.

38 S. Biełakow, Istoki i smyst nowogo riealizma ..., op. cit.

39 O. Sławnikowa, K komu jediet riewizor? Proza „pokolenija next”, „Nowyj mir” 2002, nr 9, http://magazines.russ.ru/novyi_mi/2002/9/slav.html (dostęp: 1.07.2019). 
Za promotorów i konsekratorów nowego realizmu można uznać także Mariję Riemizową, która w kilku szkicach, między innymi w eseju Świeża krew ${ }^{40}$, wyraziła jasne poparcie dla młodego pokolenia pisarzy i ich prozy non-fiction, oraz Jewgienija Jermolina (ur. 1959), który młodemu pokoleniu i ich twórczości poświęcił cały 125 numer literackiego czasopisma „Kontinient” w 2005 roku $^{41}$ oraz kilka życzliwych szkiców krytycznych na łamach tego samego czasopisma.

Ten niezwykle istotny akt konsekracji, w którym zakorzenieni i posiadający wysoką pozycję uczestnicy pola otwierają wrota dla uczestników marginalizowanych, przychodzących z postulatami zmiany reguł gry w polu, powinien, jak się zdaje, być odpowiednio obudowany instytucjonalnie. Tak również dzieje się w przypadku nowego realizmu, który wyrasta wprost z dwóch istotnych wydarzeńnagrody literackiej „Debiut”, przyznawanej w latach 2000-2016, przeznaczonej dla pisarzy do 25. roku życia (w roku 2011 granicę tę przesunięto do 35. roku życia), oraz corocznego Forum Młodych Pisarzy (do 35. roku życia), organizowanego również od 2000 roku (do dziś) w podmoskiewskiej miejscowości Lipki. Nagroda „Debiut” szybko stała się zarówno miejscem błyskawicznego awansu literackiego oraz środowiskowej konsolidacji młodych pisarzy, jak i zagrożeniem dla grup wcześniej posiadających władzę symboliczną w polu. Dlatego „Debiut” bywał przez tych ostatnich stygmatyzowany i określany mianem sekty $i$ kasty, nowego komsomotu czy wspólnej przegranej literackiego cechu ${ }^{42}$. Wśród oponentów nagrody „Debiut” znaleźli się między innymi liberalni pisarze i krytycy Dmitrij Bykow, Aleksandr Archangielski oraz Andriej Niemzier - ten ostatni oskarżał nagrodę i związanych z nią działaczy o szowinizm na tle generacyjnym, a także o brak talentu i szacunku wobec literackiej klasyki. Co ciekawe, oba te kanały awansu w dużej mierze zostały młodemu pokoleniu stworzone przez osoby spoza pola literackiego, przy nieznacznym tylko udziale „starych” graczy, co zresztą było dodatkowym czynnikiem antagonizującym „starych” i „młodych”.

\section{Powstawanie środowiska: „Debiut” i Forum Młodych Pisarzy}

Nagroda „Debiut”43 była organizowana i finansowana siłami fundacji Pokolenie, założonej i kierowanej od 1996 roku przez Andrieja Skocza ${ }^{44}$. Zasadniczym celem projektów sygnowanych i dotowanych przez fundację jest zogniskowanie

40 M. Riemizowa, Swieżaja krow', „Nowyj Mir” 2002, nr 6, http://magazines.russ.ru/novyi_ $\mathrm{mi} / 2002 / 6 / \mathrm{rem} . h t m l$ (dostęp: 1.07.2019).

41 J. Jermolin, op. cit.

42 M. Bojko, O diwnyj nowyj ..., op. cit.; D. Bykow, Bykow-quickly: wzglad 22, „Russkij Żurnał", nr 22.11.2001, http://www.pokolenie-debut.ru/press/bykov-quickly-vzglyad-22_6064 (dostęp: 1.07.2019); A. Niemzier, Igra w ktassiki: taurieaty priemii „,Diebiut”, „Wriemia Nowostiej” 2000, nr 193, http://www.vremya.ru/2000/193/10/4862.html (dostęp: 1.07.2019).

43 Zob. https://web.archive.org/web/20100702053622/http://www.pokolenie-debut.ru/ (dostęp: 1.07.2019).

44 Warto w tym miejscu wyeksponować biografię Andrieja Skocza - biznesmena, miliardera i polityka. Jest on udziałowcem ogromnego holdingu metalurgicznego Metałłoinwest, specjalizującego się w wytwarzaniu stali, współwłaścicielem firmy Mietałgaz oraz deputowanym do rosyjskiej Dumy (od 1999 roku, zaś od 2007 roku - z ramienia Jednej Rosji), w której od 2012 roku współtworzy 
poszczególnych - większych i mniejszych - segmentów społeczeństwa rosyjskiego wokół koncepcji mostu międzygeneracyjnego. Jednym z zadań fundacji było wspieranie „straconego" pokolenia pieriestrojki. Ten dyskurs o straconym czy też opuszczonym i porzuconym pokoleniu urodzonym w drugiej połowie lat siedemdziesiątych i w latach osiemdziesiątych XX wieku był zresztą inspiracją do zorganizowania nagrody „Debiut” dla pisarzy właśnie do 25. roku życia. Nie ominął on wszak pola literackiego, w którym krytycy zwracali uwagę, że nowe pokolenie pisarzy to przede wszystkim generacja uformowana w czasie pieriestrojki, której charakterystyczny przedstawiciel „walczy ze starszymi, władzą, światem konsumpcji, a także od czasu do czasu tęskni za złotym wiekem sprzed pieriestrojki, którego właściwie nie zna"45. Inni krytycy forsowali koncepcję niezakorzenionego pokolenia, które - wyrwane ze stabilnego, radzieckiego uniwersum symbolicznego i zmuszone do oglądania jego upadku - nie jest już w stanie odwoływać się ani do tego, ani do żadnego innego uniwersum symbolicznego. Pozostaje natomiast zmuszone do mozolnego budowania własnego systemu wartości, opierając na tym przekonanie o własnej wyjątkowości. Najchętniej przywoływanym określeniem było jednak , pokolenie czasu przełomu i transformacji”. W ten sposób pisały o młodej generacji między innymi Olga Martynowa i Daria Markowa - ta ostatnia poczuła w twórczości młodego pokolenia ,z jednej strony ich żelazną determinację żeby odnowić świat i życie, z drugiej - żal: dlaczego nikt się nami nie opiekuje?"46.

Nagroda „Debiut” miała zatem odzyskać spisane na straty młode pokolenie, pełniąc rolę platformy konsolidującej i kształtującej przyszłą - potencjalną - elitę kulturową. Od początku cieszyła się dużą popularnością wśród młodych pisarzy już w 2001 roku Olga Sławnikowa ogłosiła, że liczba nadsyłanych rękopisów osiągnęła 35 tysięcy egzemplarzy. Dla młodych autorów nagroda pełniła zarówno rolę zaplecza ekonomicznego - wszak jej wysokość to milion rubli w każdej z kategorii - jak i źródła prestiżu w polu, wiązał się z nią bowiem szereg działań promocyjnych i wydawniczych. Każdy z laureatów - a także finalistów - miał szansę na publikację w ramach specjalnego funduszu wydawniczego, ponadto mógł promować swoją twórczość w czasie specjalnych spotkań literackich, a także tworzyć sieci kontaktów podczas seminariów specjalistycznych ${ }^{47}$.

konserwatywną, ponadfrakcyjną grupę ds. ochrony chrześcijańskich wartości. Co ciekawe, proliteracka działalność Skocza realizowana pod szyldem Pokolenia zaczęła rozwijać się mniej więcej od momentu wejścia do Dumy. Początkowo fundacja specjalizowała się bowiem w pomaganiu dzieciom z wrodzonymi wadami serca, fundowała nagrody dla lekarzy i akademików z obszaru pediatrii i kardiochirurgii, a także wspierała materialnie zubożałych rosyjskich weteranów II wojny światowej. Przykład Skocza wydaje się świetnie obrazować fundamentalne, w przypadku rosyjskim, znaczenie przemysłu wydobywczego i ciężkiego dla finansowania produkcji kulturowej. Proliteracka działalność Skocza obrazuje mechanizm wzajemnych wpływów i powiązań między polami, potwierdzając tezę o tym, że obszar kultury oraz twórczość tego obszaru nie powstają w społecznej próżni.

45 A. Ganijewa, op. cit.

46 D. Markowa, op. cit.; zob. też: O. Martynowa, op. cit.

47 Nagrodę „Debiut” przyznaje się w czterech kategoriach podstawowych: duża proza, mała proza, poezja, dramaturgia; a także, niecyklicznie, w kategoriach: literacka krytyka i eseistyka, fantastyka, literatura dla dzieci, literatura poszukiwań duchowych oraz literatura dla kinematografii. Jeśli chodzi o liczby obrazujące skalę zjawiska - w latach 2000-2015 samych laureatów nagrody „Debiut” było 
Ponadto w 2007 roku przy nagrodzie uruchomiony został projekt Młody rosyjski świat (oryg. russkij mir), w ramach którego przyznawano nagrody dla rosyjskojęzycznych autorów mieszkających za granicą. Rada programowa „Debiutu" okresowo przyznawała także dodatkowe nagrody w ramach tworzonych ad hoc kategorii uznawanych za istotne dla rozwoju aktualnego procesu literackiego w Rosji. Tu warto wspomnieć o nagrodzie specjalnej za Męstwo w literaturze, która jasno akcentuje konserwatywną orientację ideową rady programowej całej nagrody.

Jak pisze Sławnikowa, „Debiut” był odpowiedzią na zapotrzebowanie konserwatywnej strony pola na „odrodzenie rosyjskiej literatury”48. Do roku 2000 bowiem ogromna większość funduszy przypadała projektom liberalnym oraz takim, które były nastawione na - opisywane w podrozdziale drugim niniejszej pracy - odgórne budowanie demokracji w Rosji. Tymczasem nowe „odrodzenie” traktowane było jednoznacznie jako proces reorientacji na wartości patriotyczne, na poszukiwanie ram dla nowej formy tożsamości zbiorowej opartej na starych, tradycyjnych wartościach: witalności, buncie, sile i determinacji w dążeniu do zmiany. Taka formuła pozwoliła skanalizować narastającą frustrację i gniew młodego pokolenia pisarzy, które bezskutecznie próbowało znaleźć właściwą drogę do zaistnienia w dość hermetycznie zamkniętym rosyjskim polu literackim. „Debiut" był konkurencyjnym wobec strony liberalnej wydarzeniem konsekrującym młode pokolenie nowych realistów, nadającym mu symboliczną wagę - wydarzeniem, które dowiodło trwałości pojęć nowej literatury i nowego realizmu, wcześniej tak dyskredytowanych przez liberałów.

„Debiut” stanowił pierwszy poważny i rzeczywiście skuteczny krok w kierunku nowej konsolidacji rosyjskiego pola literackiego - wokół niego udało się zgrupować wielu pisarzy, którzy od tej pory mieli poczucie, że stanowią pewną całość, do której mogą się odwoływać. Posiadanie statusu laureata lub finalisty nagrody było jednoznaczne z przynależnością do konkretnej grupy o podobnych poglądach, orientacji ideowej i wizji porządku społecznego. Chodziło przede wszystkim o skupienie energii twórczej wokół konkretnego celu społecznego oddolnego budowania społecznej, nieliberalnej alternatywy dla oficjalnych struktur władzy, przy jednoczesnym sprawowaniu względnej kontroli nad tą energią. O światopoglądową jednorodność grupy dbało odpowiednio dobierane jury, które chętnie nagradzało twórczość literatów skupionych na otaczającej ich rzeczywistości, a przede wszystkim niezadowolonych z tejże (niezależnie, czy pisali oni w konwencji realizmu, fantastyki, groteski, czy surrealizmu, choć stosunkowo najwięcej było realistów).

Drugim instytucjonalnym bastionem nowego realizmu jest wspominane wyżej Forum Młodych Pisarzy, organizowane corocznie - począwszy od roku 2000 przez Fundację Programów Społeczno-Ekonomicznych i Intelektualnych ${ }^{49}$, istniejącą z kolei od roku 1997. Jej dyrektorem nie jest już wielki przemysłowiec,

93, zaś wśród finalistów (krótka lista) znalazły się 293 osoby (wyliczenie na podstawie danych zgromadzonych na oficjalnej stronie nagrody http://www.pokolenie-debut.ru/persons, access: 17.09.2016).

48 O. Sławnikowa, op. cit.

49 Ros. Fond Socialno-Ekonomiczieskich i Intietlektualnych Programm. 
lecz działacz społeczny i polityk Siergiej Fiłatow ${ }^{50}$. Kluczowy z punktu widzenia niniejszej analizy jest program fundacji pod tytułem Młodzi pisarze Rosji ${ }^{51}$, w ramach którego odbywa się coroczny zjazd przedstawicieli młodego pokolenia w podmoskiewskim pensjonacie w Lipkach. Uczestniczy w nim zazwyczaj od 150 do 200 pisarzy rosyjskojęzycznych - przede wszystkim z Rosji i krajów Wspólnoty Niepodległych Państw - których próbki twórczości są recenzowane przez redaktorów rosyjskich grubych czasopism literackich ${ }^{52}$. Jest to więc wydarzenie o podobnej randze symbolicznej jak „Debiut”. Każdy kilkudniowy zjazd składa się z szeregu szkoleń, debat, wykładów z pisarzami, politykami, ekonomistami, socjologami i innymi specjalistami (zarówno z pola literackiego, jak i spoza niego), okrągłych stołów, spotkań z redakcjami wydawnictw i czasopism literackich, a także spotkań towarzyskich. Zamienne jest, że niektórzy z uczestników pierwszych spotkań w Lipkach obecnie sami występują w roli ekspertów i prowadzą warsztaty dla młodych pisarzy. Na zakończenie każdego zjazdu organizatorzy rekomendują do publikacji trzy grupy autorów: około połowy autorów zyskuje możliwość publikacji w ramach corocznego zbioru tekstów wydawanego w serii Nowi pisarze Rosji; około pięćdziesięciu uczestnikom przyznawane są stypendia Ministra Kultury Federacji Rosyjskiej; natomiast około dziesięciu najważniejszych nagród przypada najbardziej wyróżniającym się pisarzom: ich prace publikowane są jako osobne książki w ramach cyklu wydawniczego „Młoda literatura Rosji”.

Podobnie jak „Debiut”, Forum Młodych Pisarzy ma szereg przeciwników strona liberalna traktuje zjazd w Lipkach jako „getto młodych pisarzy” i miejsce zabawy młodych na wzór festiwalu Woodstock ${ }^{53}$, gdzie centralnym miejscem jest stołówka. $Z$ drugiej strony zwolennicy programu - a przede wszystkim jego beneficjenci - traktują to wydarzenie jako pokoleniowy akt formacyjny, a wspomnienie zawiązywanych tam przyjaźni i sojuszy zajmuje ważne miejsce $\mathrm{w}$ ich wypowiedziach publicznych. Zachar Prilepin, jeden z trzech czołowych przedstawicieli nurtu (obok Siergieja Szargunowa i Romana Sienczina), opowiada:

${ }^{50}$ W latach 90. kierownik administracji prezydenta Borysa Jelcyna i konsekwentny krzewiciel idei społeczeństwa obywatelskiego w Rosji. Podobnie jak Pokolenie, ta fundacja stawia sobie za cel promowanie programów przyczyniających się do rozwiązywania ekonomicznych i społecznych problemów ludności, przedsiębiorstw i organizacji Federacji Rosyjskiej. Fundacja rozwinęła szeroką działalność kulturalną, między innymi fundusz wydawniczy wspierający literaturę dla dzieci i młodzieży, program kultura, biznes, społeczeństwo (w ramach którego organizowane są okrągłe stoły dla przedstawicieli organizacji rządowych i pozarządowych) czy Kongres rosyjskiej inteligencji, organizowany do 2010 roku.

51 Program nie ma osobnej strony internetowej, lecz podstronę w serwisie Fiłatowa: http://www. sfilatov.ru/work/yung.php (dostęp: 1.07.2019).

52 Liczba corocznych zgłoszeń przekracza 500. W latach 2000-2015 w Forum Młodych Pisarzy udział wzięło łącznie 2507 osób (wyliczenie na podstawie list uczestników dostępnych online 12.12.2016 na portalu http://www.sfilatov.ru/).

53 A. Baszkatowa, Lipki kak getto molodych pisatielej, „NG Ex Libris”, 31.10.2013, http://www. ng.ru/ng_exlibris/2013-10-31/1_bashkatova.html (dostęp: 1.07.2019); W. Sziriajew, Poslednije Lipki, „Urał” 2013, nr 12, http://magazines.russ.ru/ural/2013/12/22sch.html (dostęp: 1.07.2019). 
Z pisarzem Romanem Sienczinem poznaliśmy się w czasie seminarium literackiego w Lipkach w 2005 roku. Niedużą grupą literatów przyszliśmy do niego do pokoju. Wtedy Roman bardzo cierpiał przez kaca i leżał twarzą do dołu. Siedziałem na parapecie, rozlewałem i wznosiłem toasty. Przy trzecim toaście Roman nieoczekiwanie zaśmiał się w poduszkę, wstał z łóżka i powiedział: Ja też wypiję. Miał na sobie ciemny sweter i czarne spodnie, w których chodzi do dziśs ${ }^{54}$.

\section{Z kolei Siergiej Szargunow wspomina:}

Pewnego razu przyjechałem do Lipek pierwszy raz, miałem dwadzieścia lat. Zarejestrowałem się, rzuciłem plecak w pokoju i zszedłem do hallu. [...] Pomyślałem - dobrze byłoby znaleźć Romana [Sienczina - przypis autora]. [...]. Poznałem go jeszcze przed Lipkami i byłem przygnębiony jego surowym sposobem bycia. Ale kiedy w końcu w Lipkach wypiliśmy po 100 gramów, przede mną siedział bystry i delikatny człowiek z otwartym wzrokiem. [...] A Wasilina [Orłowa - przypis autora]? Ildar [Abuziarow - przypis autora]? A Dimon Oriechow? Ile rozmów, wyznań, sporów, szczęśliwych chwil, nowych imion i nowych tekstów dostałem od Lipek. Tyle wspaniałości! Za to oczywiście dziękuję organizatorom - mądrym i dobrym ${ }^{55}$.

Wspomnienia uczestników wskazują przede wszystkim na atmosferę wydarzenia, wybitnie ich zdaniem sprzyjającą rozwojowi dalszej profesjonalnej kariery. Lipki stały się dla młodych pisarzy „całą planetą" ${ }^{56}$, zmaterializowanym w jednym miejscu polem literackim, gdzie poznawali mechanizmy jego działania i reguły gry. Lipki, jak się zdaje, służyły nade wszystko wzajemnemu poznawaniu się w ramach środowiska, zawiązywaniu trwałych sojuszy w polu oraz konstruowaniu punktów odniesienia, do których można się odwoływać w ramach swojej twórczej biografii. Były miejscem tworzenia się środowiska, zdobywania tożsamości pisarza przez początkujących literatów, a także miejscem pierwszej zbiorowej konsekracji pokolenia młodych pisarzy w rosyjskiej przestrzeni literackiej.

Warto dodatkowo podkreślić, że możliwość działania zbiorowego okazała się ważnym elementem tożsamości nowych realistów i wyraźnie wpływała na treść ich twórczości. Roman Sienczin w jednym ze swoich szkiców krytycznych zwraca uwagę, że już w połowie lat dziewięćdziesiątych obóz konserwatywny zaczął doceniać idee wspólnoty pisarskiej, dawno skompromitowanej przez monopolistyczny Związek Pisarzy ZSRR:

W 1996 roku odbyła się wszechrosyjska narada młodych pisarzy w Jarosławiu, w której udział wzięło ponad czterysta osób. W 1999 odbyła się kolejna w Pieriediełkinie, a trochę później - w Malejowce. Na granicy lat 90. i 2000. ukazało się kilka kolektywnych zbiorów młodej prozy: Czas rodzić, Pogoda na jutro, Antologia wspótczesnego opowiadania albo Historia końca wieku, później ukazywały się zbiory tekstów laureatów nagrody „Debiut”,

54 Z. Prilepin, Nowiejszaja istorija. Nowyj riealizm, „Sobaka”, 3.05.2012, http://www.sobaka. ru/oldmagazine/glavnoe/11550 (dostęp: 1.07.2019).

55 S. Szargunow, Diesiat' let wmiestie, „Znamia” 2010, nr 10, http://magazines.russ.ru/znamia/2010/10/d10-pr.html (dostęp: 1.07.2019).

56 S. Fiłatow, Planieta Lipki, „Znamia” 2010, nr 10, http://znamlit.ru/publication.php?id=4397 (dostęp: 1.07.2019). 
uczestników Forum w Lipkach, almanachy czasopisma internetowego Prolog oraz zbiór nagrody „Eureka" ${ }^{57}$.

Z kolei przedstawiciele obozu liberalnego krytycznie spoglądali na mechanizm konsolidacji młodego pokolenia, choć jednocześnie upatrywali w nim klucza do ich późniejszego sukcesu:

To, że oni aktywnie promowali siebie nawzajem - w artykułach, wywiadach, recenzjach (szczególnie skuteczny w tym był ,pułk Lipek”). I nie zauważali „obcych”. Dlatego pokolenie wydaje się jednokolorowe i jednolite. Ciągnie ich do siebie jak daltonistów, którzy nie rozpoznają innych kolorów. Zbili się w jedną bryłę ${ }^{58}$.

O społecznym wymiarze tego kolektywnego zwrotu w rosyjskim polu literackim szeroko pisał Ilja Kukulin. Jako pierwszy zwracał uwagę na to, że Lipki stały się maszyną do produkcji rosyjskich elit kulturowych, i wskazywał na późniejsze sukcesy niektórych absolwentów zjazdów w profesjonalnych konkursach literackich ${ }^{59}$. Kukulin zaznaczał jednak, że moc oddziaływania Lipek w pewnym momencie wyszła poza ramy kontroli samych organizatorów. Jedna ze śmielszych tez krytyka głosi, że niezależnie od tego, iż w zjeździe udział brały setki pisarzy:

Wokół Lipek sformułował się stabilny krąg składający się z 20-30 osób, które łączyły związki przyjaźni i wspólnota nie tyle estetycznych poglądów, ile wyobrażeń o procesie literackim, którą można nazwać, choć z pewnymi zastrzeżeniami, neosowiecką. Style, w jakich piszą ci autorzy, mogą nie mieć niczego wspólnego z sowiecką literaturą. Niemniej, w ciągu lat dwutysięcznych, Forum w Lipkach przekształciło się w instytucję miękkiego odtwarzania społecznych przyzwyczajeń i odruchów sowieckiej literatury. Były one składową literackiego systemu, w którym w centrum życia stały grube czasopisma literackie, podzielony na walczące ze sobą frakcje Związek Pisarzy, wspólny dla wszystkich Centralny Dom Literatów z restauracją, jednorodna dla całego kraju struktura pisarskich seminariów i $\operatorname{rad}^{60}$.

W cytowanym fragmencie Kukulin zwraca uwagę na postępującą unifikację pola, którą interpretuje jako zagrożenie dla zasady jego demokratycznej organizacji wewnętrznej. Podkreśla także ekskluzywny charakter takiego sposobu tworzenia sieci społecznych - w tym procesie widzi szczególnie zagrożenie dla autonomii pola, przypomina mu on bowiem mechanizmy funkcjonujące w polu władzy politycznej. W tej wyraźnej opozycji między zwolennikami działań kolektywnych a orędownikami indywidualnych strategii przetrwania w polu zarysowuje się kolejny antagonizm między omawianymi środowiskami, wszak zwrot przeciwko indywidualizmowi i atomizacji społeczeństwa jest jednym z głównych postulatów nowego realizmu. Jak się wydaje, zręby tego stanowiska tworzyły się

57 R. Sienczin, Pitomcy stabilnosti ili buduszczije buntari. Diebiutanty nulewych godow, „Drużba Narodow” 2010, nr 1, http://magazines.russ.ru/druzhba/2010/1/se13.html (dostęp: 1.07.2019).

58 M. Bojko, Swobodnyje radikaty-2..., op. cit.

59 Dla przykładu, Denis Gucko (ur. 1969) już w 2005 roku został laureatem Rosyjskiej Nagrody „Bookera”, Roman Sienczin znalazł się na krótkiej liście finalistów w 2009 roku, a dwa opowiadania Ildara Abuziarowa weszły jednocześnie do finału nagrody im. Jurija Kazakowa w 2005 roku. Zob. I. Kukulin, op. cit.

60 Ibid. 
w środowiskach związanych z Lipkami i ,Debiutem” i dokładnie stamtąd wyrastają.

\section{Podsumowanie}

Chociaż samo sformułowanie nowy realizm pojawiło się w dyskursie rosyjskiego świata literackiego już w latach dziewięćdziesiątych XX wieku, początkowo nie znalazło tam szerszego uznania. Największą karierę zrobiło ono dopiero po roku 2000, natomiast już w okolicy roku 2010 na stałe zagościło w rosyjskim procesie historycznoliterackim. Co istotne, zarówno w swej fazie początkowej (nazywanej pierwsza fala), jak i w fazie szczytowej (nazywanej druga fala) nowy realizm wydaje się pierwszym tak spójnym zjawiskiem rosyjskiego pola literackiego, które jednoznacznie uformowało się już po rozpadzie Związku Radzieckiego. Niniejszy artykuł miał za cel pokazać, że nowy realizm od początku był zjawiskiem pojemnym i warto patrzeć na nie szerzej niż tylko w kategoriach nurtu literackiego. Młode pokolenie pisarzy i krytyków jednoczących się pod hasłem nowego realizmu walczyło bowiem dla siebie o odrębne miejsce w polu literackim oraz w dyskursie publicznym, o prawo do udziału w nim na własnych warunkach.

\section{Bibliografia}

Aksionow I., My nie kastraty, my - sołdaty, „NG-Exlibris”, http://www.ng.ru/ng_exlibris/2004-11-18/6_soldiers.html (dostęp: 1.07.2019).

Baszkatowa A., Lipki kak getto mołodych pisatielej, „NG-Exlibris”, 31.10.2013, http://www.ng.ru/ng_exlibris/2013-10-31/1_bashkatova.html (dostęp: 1.07.2019).

Biełakow S., Drakon w tabirintie: $k$ tupiku nowogo riealizma, „Urał” 2003, nr 10, http://magazines.russ.ru/ural/2003/10/bel.html (dostęp: 1.07.2019).

Biełakow S., Istoki $i$ smyst nowogo riealizma: $k$ litieraturnoj situacii nulewych, Materiały Konferencji Związku Pisarzy Rosji Itogi litieraturnogo goda - itogi diesiatiletija: jazyk - litieratura - obszczestwo, Moskwa, http://www.rospisatel. ru/konferenzija-itogi.htm (dostęp: 1.07.2019).

Biełakow S., Nowyje bielinskije i gogoli na czas, „Woprosy litieratury” 2007, nr 4, http://voplit.ru/eText/2007/2007-4/2007-4/2007-4.html\#79 (dostęp: 1.07.2019).

Biełakow S., Zabłudiwszijsja drakon, „Czastnyj korriespondient”, 17.03.2010, http:// www.chaskor.ru/article/zabludivshijsya_drakon_15990 (dostęp: 1.07.2019).

Bojko M., O diwnyj nowyj riealizm, „Litieraturnaja gazieta” 2010, nr 12 (6267), http:// www.lgz.ru/article/N12--6267---2010-03-31-/O-divn\%D1\%8By-nov\%D1\%8Byr\%D0\%B5alizm12106/ (dostęp: 1.07.2019).

Bojko M., Swobodnyje radikaty-2. Manifiest proigrawszej storony, „NG-Exlibris”, 25.02.2010, http://www.ng.ru/ng_exlibris/2010-02-25/5_radikaly2.html (dostęp: 1.07.2019).

Bojko M., Wzlot i padienije N-riealizma, Materiały Konferencji Związku Pisarzy Rosji Itogi litieraturnogo goda-itogi diesiatiletija: jazyk-litieratura-obszczestwo, Moskwa 2010, http://www.rospisatel.ru/konferenzija/boiko.htm (dostęp: 1.07.2019). 
Bołszakowa A., Sowriemiennyj litieraturnyj proces: tiendencii $i$ pierspiektiwy, Materiały Konferencji Związku Pisarzy Rosji Itogi litieraturnogo goda - itogi diesiatiletija: jazyk - litieratura - obszczestwo, Moskwa 2010, http://www.rospisatel.ru/konferenzija/bolshakova-doklad.htm (dostęp: 1.07.2019).

Bondarienko W., Nuliewyje, Materiały Konferencji Związku Pisarzy Rosji Itogi litieraturnogo goda - itogi diesiatiletija: jazyk - litieratura - obszczestwo, Moskwa 2010, http://www.rospisatel.ru/konferenzija/bondarenko.htm (dostęp: 1.07.2019).

Bondarienko W., Popytka prorywa, „Litieraturnaja Gazieta” 2010, nr 13 (6268), http://www.lgz.ru/article/N13--6268---2010-04-07-/Pop\%D1\%8Btkapror\%D1\%8Bva12210/ (dostęp: 1.07.2019).

Bourdieu P., Reguty sztuki. Geneza i struktura pola literackiego, tłum. A. Zawadzki, Kraków 2001.

Buksza K., Alonka-partizanka, Sankt Petersburg 2002.

Bykow D., Bykow-quickly: wzgliad 22, „Russkij Żurnał”, 22.11.2001, http://www. pokolenie-debut.ru/press/bykov-quickly-vzglyad-22_6064 (dostęp: 1.07.2019).

Cziornyj D., Manifiest i mietody radikalnogo riealizma, Moskwa 2001.

Cziornyj D., Manifiest radikalnogo riealizma, 30.03.2000, „Stihi.ru”, http://stihi. ru/2011/04/05/4307 (dostęp: 1.07.2019).

Dawydowa T., Russkij nieoriealizm: idieołogija, poetika, tworczieskaja ewolucija (E. Zamiatin, I. Szmielew, M. Prisziwin, A. Płatonow, M. Bułgakow i dr.): Ucziebnoje posobije, Moskwa 2006.

Fiłatow S., Płanieta Lipki, „Znamia” 2010, nr 10, http://znamlit.ru/publication. php?id=4397 (dostęp: 1.07.2019).

Frołow I., Czudiszcze stoziewno i biezjazyko, „Litieraturnaja gazieta” 2010, nr 11 (6266), http:/www.lgz.ru/article/N11--6266---2010-03-24-/Chudisht\%D0\%B5stoz\%D0\%B5vno-i-b\%D0\%B5zayaz\%D1\%8Bko12025/ (dostęp: 1.07.2019).

Ganijewa A., Wozrożdienije koncepta ,,Mołodyje pisatieli” w nulewyje gody, Materiały Konferencji Związku Pisarzy Rosji Itogi litieraturnogo goda-itogi diesiatiletija: jazyk - litieratura - obszczestwo, Moskwa 2010, http://www.rospisatel.ru/konferenzija/ganieva.htm (dostęp: 1.07.2019).

Golenko Ż., Czitat' modno!, „Woprosy litieratury” 2004, nr 5, http:/voplit.ru/ eText/2004/2004-5/2004-5/2004-5.html\#6 (dostęp: 1.07.2019).

Jaszin A., Manifiest nowogo russkogo kriticzieskogo riealizma, „Priokskije Zori” 2011, nr 1, http://www.rospisatel.ru/manifest-nkr.htm (dostęp: 1.07.2019).

Jermolin J., Mołodoj Kontinient, „,Kontinient” 2005, nr 125, http://magazines.russ.ru/ continent/2005/125/ee1.html (dostęp: 1.07.2019).

Jerofiejew W., Stypa po literaturze sowieckiej, przeł. A. Pomorski, „Res Publica” 1991, nr 6, s. 36-41.

Kukulin I., ,, Kakoj szcziot?”. Kak gławnyj wopros russkoj litieratury, „Znamia” 2010, nr 4, http://magazines.russ.ru/znamia/2010/4/ku19.html (dostęp: 1.07.2019).

Lipowieckij M., Nowyj riealizm - eto rannij simptom zatjażnoj boliezni, „Colta.ru”, 23.04.2014, http://www.colta.ru/articles/literature/3003 (dostęp: 1.07.2019).

Markowa D., Nowyj-prienowyj riealizm, ili opiat'dwadcat' piat', „Znamia” 2006, nr 6, http://magazines.russ.ru/znamia/2006/6/ma12.html (dostęp: 1.07.2019).

Martynowa O., Zagrobnaja pobieda socriealizmu, „OpenSpace.ru”, http://os.colta.ru/ 
literature/events/details/12295/ (dostęp: 1.07.2019).

Niemzier A., Igra $w$ klassiki: taurieaty priemii „Diebiut”, „Wriemia Nowostiej” 2000, nr 193, http:/www.vremya.ru/2000/193/10/4862.html (dostęp: 1.07.2019).

Orłowa W., Diebiut wieczien, „NG-Exlibris”, http://www.ng.ru/ng_exlibris/2004-11-18/6_debut.html (dostęp: 1.07.2019).

Prilepin Z., Nowiejszaja istorija. Nowyj riealizm, „Sobaka”, 3.05.2012, http://www. sobaka.ru/oldmagazine/glavnoe/11550 (dostęp: 1.07.2019).

Pustowaja W., Porażiency i prieobraziency (o dwuch aktualnych wzgladach na riealizm), „Oktiabr'” 2005, nr 5, http://magazines.russ.ru/october/2005/5/pust18.html (dostęp: 1.07.2019).

Rancière J., Dzielenie postrzegalnego. Estetyka i polityka, tłum. M. Kropiwnicki, J. Sowa, Kraków 2007.

Rancière J., Estetyka jako polityka, tłum. P. Mościcki, J. Kutyła, Warszawa 2007.

Rancière J., The politics of literature, thum. J. Rose, Cambridge-Malden 2011.

Riemizowa M., Swieżaja krow', „Nowyj Mir” 2002, nr 6, http://magazines.russ.ru/ novyi_mi/2002/6/rem.html (dostęp: 1.07.2019).

Rubanowa N., Kiłogrammy bukw $w$ razwies $i$ w rozliw, „Znamia” 2006, nr 5, http:// magazines.russ.ru/znamia/2006/5/ru15.html (dostęp: 1.07.2019).

Sienczin R., Pitomcy stabilnosti ili buduszczije buntari. Diebiutanty nulewych godow, „Drużba Narodow” 2010, nr 1, http://magazines.russ.ru/druzhba/2010/1/se13. html (dostęp: 1.07.2019).

Sławnikowa O., K komu jediet riewizor? Proza „,pokolenija next”, „Nowyj Mir” 2002, nr 9, http://magazines.russ.ru/novyi_mi/2002/9/slav.html (dostęp: 1.07.2019).

Szargunow S., Diesiat' let wmiestie, „Znamia” 2010, nr 10, http://magazines.russ.ru/ znamia/2010/10/d10-pr.html (dostęp: 1.07.2019).

Szargunow S., Otricanije traura, „Nowyj Mir” 2001, nr 12, http://magazines.russ.ru/ novyi_mi/2001/12/shargunov.html (dostęp: 1.07.2019).

Szargunow S., Stratiegiczieski my pobiedili, ,Kontinient” 2005, nr 125, http://magazines.russ.ru/continent/2005/125/sh26-pr.html (dostęp: 1.07.2019).

Szargunow S., Ura!, Moskwa 2003.

Sziriajew W., Posliednije Lipki, „Urał” 2013, nr 12, http://magazines.russ.ru/ ural/2013/12/22sch.html (dostęp: 1.07.2019).

Szubinskij W., Szto i pocziemu, „Oktiabr”” 2010, nr 2, http://magazines.russ.ru/october/2010/2/s15.html (dostęp: 1.07.2019).

Tuzkow S., Tuzkowa I., Nieoriealizm: żanrowo-stilewyje poiski w russkoj litieraturie konca XIX-naczała XX wieka: Ucziebnoje posobije, Moskwa 2009. 